\title{
Çeçen Halkının Kendi Kaderini Belirleme Hakkı
}

\author{
The Self Determination Rights of Chechen People
}

\section{İrfan SÖNMEZ}

Dr., Avukat - Elazığ Barosu, efe_23_23@hotmail.com

https://orcid.org/0000-0002-7045-9023
Makale Başvuru Tarihi: 20.12.2019

Makale Kabul Tarihi: 29.12.2019

Makale Türü: Araştırma Makalesi

\author{
Murat AYGEN \\ Dr. Ögrr. Üyesi, Furat Üniversitesi, $\ddot{I} B F$, \\ Siyaset Bilimi ve Kamu Yönetimi Bölümü, \\ maygen@firat.edu.tr \\ https://orcid.org/0000-0003-4021-9675
}

\begin{abstract}
Anahtar
Kelimeler:

Self-

Determinasyon,

Ayrllma Hakkl,

Milliyetçilik,
\end{abstract}

Çeçenistan,

Rusya,

Keywords:

Self-Determination,

Seperation Right,

Nationalism,

Chechenia,

Russia,

\section{ÖZET}

Uluslararası hukuk -halkların- kendi geleceklerini belirlemelerini bir insan hakkı olarak görmektedir.20.yüzyılda popülerlik kazanan kavram imparatorlukların ve sömürgeciliğin tasfiyesinde önemli rol oynamıştır. Hakkın öznesi halklar olmasına rağmen uluslararası toplumun her halka aynı duyarlılıkla yaklaştığını söylemek mümkün değildir. Bu halklardan biri de Çeçenlerdir. Çeçenler, 17. yüzyıldan beri Rus işgaline karşı mücadele vermektedir. Sovyetlerin dă̆lmasından sonra kısa bir süre defacto devlet olmalarına rağmen, Rusya'nın müdahalesi ile özgürlüklerini kaybetmişlerdir. Çeçenler dilleri, dinleri ve kültürleri ile Ruslardan ayrı bir halktır. Bu bakımdan Rus yayılmacılığına karşı asırları aşan bir direnç göstermişlerdir. Günümüzde yarı özerk bir statüye sahip olan Çeçenistan sürgün ve klyımlara rağmen hala kendi kaderine hükmetme arzu ve potansiyelini korumaktadır. Bu makale, Rus hegemonyasına karşı Çeçen halkının selfdeterminasyon hakkının olup olmadı̆̆ını tartışmaktadır.

\section{ABSTRACT}

International law accepts the self-determination rights of people as a human right. The concept of selfdetermination has been popular in 20 th century and played an important role in eliminating colonialism and collapsing of empires. Although the subject of the right is people, it is difficult to say that the international community approach to each people/nation with equal sensitivity. One of these people/nations is Chechen nation. Chechens have been fighting against Russian occupation since 17 th Century. Though they gained their de facto independence for a short time after the collapse of the Soviet Union, they lost this independence with Russian intervention. Chechens are different nations from Russians in terms of religion, language and culture. So they have resisted Russian expansion for over the long centuries. Today by being a semi autonomy status, they still keep the willingness and potential of self-determination right. This essay examines and discuss whether the Chechen nation has self-determination right or not against Russian hegemony. 


\section{GIRISS}

Çeçen sorunu Kafkasların en önemli ve en uzun geçmişe sahip sorunlarından biridir. Sınır tanımayan Rus yayılmacılığı ve değişmeyen emperyal vizyonu sorunun en önemli sebebini teşkil etmektedir. Bünyesinde farklı milletleri barındıran Rusya, soruna -domino teorisi- açısından bakmakta herhangi bir halka özgürlük vermenin diğerlerini de aynı yönde yüreklendireceğini düşünmektedir. Onun için Çeçen halkının her özgürlük hamlesini kanla bastırmıştır. Devasa gücüne rağmen Rusya bölgede sürekli bir hâkimiyet kuramamış, Çeçenistan'ın cüssesi ile ölçülmeyecek bir direnişle karşılaş̧ıştır. Konjonktüre ve Rusya'nın güç ve baskısına göre değişen bu direniş günümüze kadar devam etmiştir.

Sovyetlerin dağılmasından sonra ivme kazanan -kendi kaderine- hükmetme düşüncesi çeşitli nedenlerle etkisiz kalmıştır. Bu nedenlerin bazısı güç dengeleri ve uluslararası konjonktürle ilgili diğer bazısı ise bizzat Çeçen halkının ve Kafkas halklarının sosyolojik yapılarıyla ilgilidir.

Günümüzde self-determinasyon hakkına sahip olmak kendi kaderini belirlemeye yetmemektedir. Hak sahibi olmakla o hakkı elde etmek arasında ciddi farklar vardır. Uluslararası ilişkilerde hala milli çıkarlar ve güç ögesi hukukun önünde gelmektedir.

Meselenin bir boyutu da kendi kaderini tayin yoluyla giderek parçalanmış bir dünyanın uluslararası toplumu nereye götüreceği endişesidir. Çünkü self-determinasyon daha çok dişsal anlamda kullanılmakta, ayrılık taleplerinin bir manivelası haline getirilmektedir. 1944'de İzlanda'nın Danimarka'dan kopmasından 1991'de Komünizmin çökmesine kadar geçen sürede sadece üç ulusal ayrılıkçı hareket başarılı olmuştur. Bunlar, Singapur, Bangladeş ve Eritre'dir. Bu tarihten sonra ulusal ayrılıkçı hareketlerde gözle görülür bir artış meydana gelmiştir.

Ayrılıkçı hareketler için anahtar bir kavram haline gelen self-determinasyon bazı çevrelerde etnik çatışmaları sonlandıran bir maymuncuk olarak değerlendirilmektedir. Ancak başkalarına uygulandığında son derece iştahlı olan devletler, sira kendilerine gelince bu kavrama son derece mesafeli durmaktadirlar.

Çalışma, Çeçen halkının hürriyet mücadelesi ve kendi kaderini tayin hakkı bakımından durumunu konu edinmektedir. Bu çerçevede meselenin tarihi arka planı genişçe ele alınmış, Çeçen halkının self-determinasyon hakkına haiz olup olmadığı Uluslararası Hukukun konuyla ilgili prensipleri dikkate alınarak ortaya konulmuştur.

\section{SELF-DETERMINASYON}

Self-determinasyon günümüzün sembol kavramlarından biridir. Geçmişte imparatorlukların parçalanması ile sömürgeciliğin tasfiyesinde önemli rol oynamıştır. Bugün dünyada devam eden çatışmaların büyük kısmı etnik kökenli olup, çoğu, halkların kendi kaderini tayin hakkına dayanarak özerklik veya bağımsızlık elde etmeye çalışmaktadır.

Self-determinasyon (SD), birçok uluslararası belgede ifade edilmesine rağmen, dengeleri ve statükoyu bozabileceği endişesiyle devletler tarafından ihtiyatla karşılanan bir kavramdır (Caşın, 2013:392). Haritaları değiştirebilecek gücü, devletleri ürkütmekte, kavrama ihtiyatla yaklaşmalarına neden olmaktadır. Bunun temel nedenlerinden biri, hemen her kavramın büyük devletlerin elinde bir istismar aracına dönüştürülmesi, halkların huzur ve barışı için değil, ülkelerin bölünüp, parçalanması için kullanılmasıdır.

Kavramın en çok paylaşılan tanımlarından biri, bir ülkede yaşayan halkın kendi yönetim biçimini özgürce seçebilmeleridir (Caşın, 2013:392). Bu tanımı popüler kılan kavramı iç siyasi tercihlerle sınırlı tutması, bir anlamda demokrasi ile eşitlemesidir. Ancak, ayrılma özgürlügüne vurgu yapan, bu olmadıkça kavramın bir anlam ifade etmeyeceğini belirten yazarlar da vardır. Allen Buchanan, bunlardan biridir ve böyle bir sınırlamanın kendi kaderini tayin hakkı ile bağdaşmayacağını belirterek, uluslararası hukukun tüm halklar ve uluslar için ayrılma hakkı tanıması gerektiğini ifade etmiştir (Nimni, 2016:182). Bu yöndeki bir başka tanım, self determinasyonu; dil, din veya başka bir açıdan kendini farklı gören gurupların ayrı bir egemenlik alanı oluşturmak amacıyla mevcut sınırların yeniden düzenlenmesini istemesi olarak tanımlar (Kılıç, 2008:953).

Dolayısıyla Self-determinasyon fikrinin temelinde, ülke sınırları içinde ya da dışında kendisini yalnız hisseden, diğer insanlarla birlik olan bir grup insanın bir diğer grupla karşılıklı olarak bazı sosyal bağları paylaşması sonucu kendi devletini kurmak istemeleri vardır diyen Kelsen de aynı görüştedir (Eminoğlu, 2015:129). Karşıt görüşte olanlar ise, SD ile toprak bütünlüğü ilkesinin birlikte ve etkileşim içinde değerlendirilmesi gerektiğini aksi takdirde Mali-Burkina Fasso davası yargıçlarından Georges Abi-Saab'ın ifadesiyle, SD hakkının ancak bir 
serap olarak kalacağını, kargaşanın insan haklarının önünü açmayacağını belirtmişlerdir (Karaosmanoğlu, 2003:152).

Gassalse, devlet olmak isteyen topluluklar için SD'nin devletler kulübüne girmenin anahtarı olduğunu, üçüncü dünyada ortaya çıkan birçok yeni devletin doğuşuna ebelik yaptığını ifade etmiştir (Cassese, 1998:6). Kavramın netleştirilmesinde BM şartı ile Genel kurul kararlarının büyük katkısı olmuştur. BM Şartının 1(2) ile 55. maddelerinde ilk defa tüm halklar için geçerli olan bir hukuk ilkesi olarak tanımlanmış, 1514(XV), 1541(XV) ve 2625(XV) sayılı Genel Kurul kararları ile de içeriği doldurulmuştur. Son olarak İkiz Sözleşmelerin ortak 1. maddesi ile de siyasi bir ilke olmaktan çıkıp bir hak olarak kodlanmıştır.

Günümüzde self-determinasyon her iki tanımı içine alacak tarzda bir insan hakkı olarak kabul edilmektedir. Birinci tanım iç self-determinasyona, ikinci tanım dış self-determinasyona işaret etmektedir. Kavramın bir üçüncü boyutu da ekonomik self-determinasyondur. Gerçek bağımsızlığın ancak ülke kaynaklarının özgürce kullanılması ile mümkün olacağı, kendi kaynakları üzerinde söz hakkı olmayan bir halkın kendi kaderini tayin etmiş sayılamayacağı kabul edilmektedir.

SD hakkının yorumunda daha çok iki liberal teori öne çıkmaktadır. Bunlar "Haklı Neden Teorisi" ile "Tercih Teorisi"'dir. Haklı neden teorisi, adından da anlaşılacağı üzere ayrılma hakkını haklı bir nedenin varlığına bağlamaktadır. Teorinin çıkış noktası, bireylerin haklarına saygıdır. Ulusal bir topluluğun meşruiyeti buna bağlıdır. Bu haklara saygı gösterildiği müddetçe herhangi bir ayrılma talebinin meşruluğu olmayacaktır. Meşruluk için ağır insan hakları ihlallerinin yanında süreklik de şarttır. Bu teorinin en önemli savunucularından Buchanan'a göre; bir grup, sistematik hak ihlalleri, soykırım ve haksızlıklarla karşı karşıya kaldığı zaman, kendini korumak için son çare olarak ayrılma hakkına başvurabilir (Buchanan, 1991:25).

Tercih Teorisine göre ise herhangi bir yerde oturanların çoğunluğunun ayrılmayı tercih etmesi yeterlidir. Tercih teorilerini haklı neden teorisinden ayıran en önemli fark insan hakları ihlallerini SD için ne gerekli ne de yeterli şart olarak görmesidir (Kalaycı, 2010:75). En önemli savunucularından Harry Beran, devleti toprağa temelli gönüllü bir birlik olarak tarif ederek, bu birlikten çıkmayı göç ile sınırlı tutmayarak ayrılma hakkıyla da serbest bırakmıştır. Beran, bir yerde çoğunluk oluşturan, kendini farklı gören ve siyasal bir varlık olarak yaşayabilecek her grubun ayrılma ve SD hakkına haiz olduğunu ifade etmiştir (Beran, 1987:36).

Kendi kaderini tayin halklara tanınan bir haktır. Ancak herkesin kabul ettiği ortak bir halk tanımı yoktur. Böyle bir taleple karşılaşmak istemeyen ülkeler, -kendi içlerine bakarak- kendilerinde olmayan tanımlara yönelmektedir. Bu da hakkın muhatabını muğlaklaştırmakta, self-determinasyonu sahibi olmayan bir hak haline getirmektedir. Mesela, 1966 tarihli İkiz Sözleşmelerin ortak birinci maddesi bütün halklardan bahsetmekte (Taşdemir ve Özer, 2017:33) ancak, halkın tanımını vermemektedir. 1989 yılında UNESCO tarafindan hazırlanan bir belgede halkın tanımı verilmemekle birlikte hangi özelliklere sahip olması gerektiği şu şekilde ifade edilmiştir: Ortak bir tarihi gelenek, rrki yahut etnik bir kimlik, kültürel türdeşlik, ortak bir dil, dinsel ya da ideolojik beraberlik, bölgesel bağ ve ortak iktisadi yaşam. Bu özelliklerin tamamını veya bazılarını paylaşan, halk olma bilincine ve bunu ifade etme araç ve kurumlarına sahip olan, yeterli bir nüfusa ulaşan topluluklar halk olarak mütalaa edilirler (Ehtibarl1, 2016:34-35). Teori, ayrılma için herhangi bir şartta gerek görmediği için sınırsız siyasal parçalanmalara neden olacağı eleştirilerine maruz kalmıştır.

Halkın, bütün siyasi aktörler tarafından paylaşılan bir tanımının olmaması iki sonuca neden olmaktadır. İçinde farklı toplulukları barındıran devletler açısından SD hakkı sahipsiz kalırken, ayrılıkçı amaçlar güden topluluklar açısından içine her topluluğun girdiği bir torba kavrama dönmektedir. Günümüzde hemen her ayrılıkçı hareketin kendini halk olarak tanımlamasının arkasında bu tanımsızlığın sağladığı avantaj vardır.

Farklı etnik ve dinsel grupların kendilerini hakkın öznesi sayma gayretlerine rağmen BM uygulamaları bu hakkı azınlıklara tanımamıştır. BM Genel Kurulunun Transkei (1976), Bophutatswana (1977), Venda (1979) ve Ciskei (1981) birimlerinin bağımsızlık ilanlarının batıl olduğuna dair kararları bunu teyit etmekte, BM'nin ülkesel kriteri esas alarak hareket ettiğini göstermektedir. Bu, BM'nin kendi kaderini tayin hakkını sömürgeci ve yabancı tahakkümü altındaki ülkelerle sınırlandırdığı anlamına gelmektedir. BM'nin 1971 yılında Bengladeş'in Pakistan'dan,1993'de Eritre'nin Etiyopya'dan ayrılmasında ülkesel ölçütten ayrılan kararları olmasına rağmen genel bir değerlendirme yapıldığında SD hakkının;

- Sömürge rejimi altında yaşayan,

- Irkçı rejimler altında yaşayan,

- Yabancı işgali altında yaşayan halklara tanınmış olduğu söylenebilir. 
SÖNMEZ, İrfan ve AYGEN, Murat - Çeçen Halkının Kendi Kaderini Belirleme Hakkı

Ancak Sömürge rejimi -tuzlu su doktrini- ile (sömüren ile sömürgesi arasında tuzlu su, deniz, okyanus bulunması) ve etnik olarak farklı olmakla, yabancı işgali ise yakın geçmişteki işgallerle sınırlandırılmıştır.

\section{3. ÇEÇENISTAN}

Kuzeyinde Rusya, doğusunda Dağıstan Cumhuriyeti, güneyinde Gürcistan, batısında İnguşetya ile çevrili olan Çeçenistan'ın kuzeyi ovalardan, güneyi dağlık alanlardan oluşmaktadır. Nüfusu 2016 yılı itibarıyla, 1.394.000, yüz ölçümü de 17.300 kilometre karedir ( www.tasam.org/tr). Bölge çeşitli yeraltı kaynaklarına sahiptir. Zengin Hidrokarbon kaynakları, çatışma ve istikrarsılı ı̆ın nedenlerinden biridir.

\subsection{Tarihi Gelişim}

Çeçenler, Kuzey Kafkasya'nın yerli halklarından olup, geçmişleri ile ilgili ilk yazılı belgeler M.Ö. 4-3 yüzyıllara kadar gitmektedir. M.S. 1. yüzyılda Alan Kavimler birliğine katılan Çeçenler zamanla çoğalarak bölgenin kalabalık topluluklarından biri haline gelmişlerdir (Akıl ve Küçükali, 2010:11). Çeçenler ile Rusların ilk teması, Altın Ordu devletinin yıkılmasından sonrasına tekabül eder. Ahmadov, Çeçenler ile Rusya arasındaki ilişkileri dört döneme ayırır (Ahmadov, 2000:12):

- Birinci dönem; 15-16. yüzyıllarda Çeçen-İnguş zümrelerin Ruslarla ilk temasının olduğu ve Rus politikasına eğilim gösterdikleri, ticari ilişkilerin ilk başladığı dönemdir.

- İkinci dönem; 18. yüzyılda Büyük Petro ile Rus politikasının Kafkasya'da daha aktif hale geldiği, ilişkilerin arttığı, Rusya ile yakınlığın Osmanlı ve İran yakınlığını geçtiği, yüzyılın ortasına kadar süren dönemdir.

- Üçüncü dönem; 18.yüzyılın 50 ile 80 yılları arasında kalan Rusların zor kullanarak bölgeye hâkim olmak istedikleri dönemdir.

- Dördüncü ve son dönem ise, 1780'lerden 1850'li yıllara kadar süren Rusların Çeçen-İnguş topraklarını zapt ettiği dönemdir.

Rus Çarlığının yayılmacı politikaları, Altın Orda devletinin yıkılması ile başlamıştır. 1654'de başa geçen Çar 1 . Petro ile 1762 'de başa geçen Katherina dönemi yayılmacı politikaların zirveleștiği dönemdir. 17 ve 18. asırlarda taraflar arasında ticari ilişkilerin gelişmesi, bölgedeki Çeçen-İnguş zümreleri ile Rus Çarlığı arasındaki ilişkileri kuvvetlendirmiştir. Nitekim 1769-1774 Osmanlı Rus savaşında Halife'nin cihat ilanı bölgede etkili olmamış, Çeçenlerin bir kısmı Türklere karşı Rusların yanında yer almıştır (Ahmadov, 2000:12).

Osmanlı'nın bölgede güç kaybetmesinden sonra Ruslar, Kafkaslarda hâkimiyet kurabilmek için Kafkas halkları ile uzun süreli bir savaşa giriştiler (www.stratejikortak.com/tr). Ele geçirdikleri topraklarda sömürgeci ve acımasız politikalar izlediler. Çeçen sorunu, Rusların 1783'de Azak Kalesini ele geçirerek bölgeye komşu olması ile başlamıştır: 18. yüzyılın ikinci yarısında Kırım ve Kabardiya'yı topraklarına katarak, Gürcistan'ı himayesine alması ve Kafkas hattını tamamlama isteği Çeçen-İnguş topraklarına yönelmelerine neden olmuştur (Ahmadov, 2000:102).

Diğer Müslüman halklar gibi Çeçenler de Rus Çarlığının yayılmacılığına karşı direndiler. Bu direniş, aralıklı olarak 19. ve 20. yüzyıllar boyunca devam etti. Ruslara karşı ilk silahlı mücadele, Şeyh Mansur liderliğinde bugünkü Çeçenistan'ın dağlık bölgesinde başlatıldı. Osmanlı devleti tarafından da desteklenen Şeyh Mansur, uzun ve kanlı bir mücadeleden sonra 1791'de ele geçirilince direniş de bastırılmıştır (www.academia.edu).

Şeyh Mansur'dan sonra 1834- 1859 yılları arasında bu defa Şeyh Şamil liderliğinde uzun ve kanlı bir direniş mücadelesi başlatıldı. Rusların üstün silah ve sayı gücü Çeçenler'in savaşı kaybetmesine neden oldu. Rusya bölgeye kısa bir süre, ancak Şeyh Şamil'in 1859'da silah bırakmasından sonra hâkim olabildi. Çeçen ve Kuzey Kafkasya halklarının direnişinde Müridizm hareketinin önemli bir rolü olmuştur (www.stratejikortak.com/tr). Çeyrek asır süren bu mücadele Çeçenlerin milli hafızalarında derin izler bıraktı, sonraki yıllarda direniş ve ayağa kalkışın sembolü oldu.

Müridizm hareketinin kökleri 18.yüzyıla kadar uzanmaktadır. Mürit, İslam tasavvufunda, kendisini İslam'a adamış, bu amaçla bir tarikat büyügünün manevi rehberliğini kabul etmiş kişidir. Ancak, bu kavram, Kafkasya'da yepyeni bir anlam kazanarak, Rus istilasına karşı bir başkaldırı ve vatan mücadelesi hüviyetine bürünmüştür. Ruslar, bu kavramı, Kafkasya'da Ortadoksluğa ve Rus yayılmacıllı̆gna karşı direnen politik ve dini bir hareket olarak tanımladıkları Nakşibendi-Halidi tarikatı müntesipleri için kullanmıştır. Asırlar boyu 
büyük güçlerin gölgesinde kalmış, kabile ve feodalitenin hâkim olduğu bölgede, bir devlet fikrinin ortaya çıkmasında 18. yüzyılda Kafkasya'ya gelen bu tarikatların, Müslüman unsurları örgütlemelerinin büyük etkisi olmuştur (www.amazonaws.com/tr).

Çeçen-Rus mücadelesi, milliyetçi ögeler taşıyan bir hareketten ziyade, cihat fikrini esas alan, Ortadoks Rus Çarlığına karşı yapılan bir mücadeledir. Dönemin şartları dikkate alınarak tüm yönleri ile değerlendirildiğinde, ülkelerini kolonileştirmek isteyen Ruslara karşı dağlı halkların haklı bir tepkisi ve gaza yoluyla ülkelerini kurtarma gayreti olduğu söylenebilir (Yeşil, 2018:3). Çarlık güçlerinin Kafkasya'yı işgalinden sonra bölgede yaşayan toplulukların büyük kısmı ülkelerinden zorla sürülmüşlerdir. Geriye kalanlar ise, -suni olarak siyasal bölgelere bölünüp- farklılıkları derinleştirilerek (dil, kültür ve folklorları) bir üst kimlik oluşturmaları engellenmiştir (Aslan, 2006:104).

\subsection{Bolşevik Devriminden Sonrası Yaşanan Gelişmeler}

Bolşevik devriminden sonra da Çeçen halkının kaderi değişmedi. Çarlığın dağılıp yerine Bolşevik bir yönetimin kurulması üzerine Kuzey Kafkasya halkları karışıklıklardan yararlanarak bağımsızlık için harekete geçtiler. 11 Mayıs 1918'de Çeçenistan'ı da içine alan Kuzey Kafkasya Cumhuriyeti kuruldu. Kızıl Ordu, iç karışıklıkları bastırıp Çar'lık yanlılarını yendikten sonra 1920 başlarında Çeçenistan'a girdi. Uzun ve şiddetli çatışmalardan sonra üstün silah ve asker gücüne sahip olan Bolşevikler galip geldi (www.stratejikortak.com).

20 Ocak 1921'de bugünkü Osetya'nın başkenti olan Vladikafkas'ta Dağl1lar Kongresi toplandı. Moskova bu toplantıya o zaman Milletler Halk Komiseri olan Stalin'i gönderdi. Stalin Kongrede, Sovyet Hükümeti'nin Dağlıların iç egemenliğini ve bağımsızlığını tanıdığını ancak tek bir Sovyet Dağ Cumhuriyetinin kurulmasını tavsiye etti. Dağlilar, bu tavsiyeye uyarak Çeçenistan, Osetya, İnguşetya, Kabarday, Balkar, Karaçay ve Dağıstan'ı içine alan Sovyet Dağ Cumhuriyetini kurdular. Her iç bölgenin başına Devrimde yararlık göstermiş̧ radikal bir Bolşevik getirildi. Anlaşmaya göre; Moskova yönetimi cumhuriyetin içişlerine karışmayacak, devlet İslam ve gelenek hukukuna göre yönetilecekti. Bunun taktiksel bir taviz olduğu çok geçmeden ortaya çıktı. Bolşevik Devrimi gücünü pekiştirinceye kadar böyle bir ara formül bularak dağlı halkları idare etmişti. Nitekim 1924 yılında Sovyet Dağ Cumhuriyetine son verildi. Çeçen-İnguş bölgesinde kurulan hükümet, her eve bir silah teslim etme zorunluluğu getirdi (Şahin, 2000).

1929 yılına gelindiğinde Stalin'in sosyalist kampanyası yeni bir sindirme ve yok etme harekâtı daha başlattı. İlk toplu tarım uygulamasına köylülerin mallarına el konularak Kafkasya'da geçildi. Direnenler tutuklanarak Sibirya'ya gönderildi (www. robertcutler.org/tr). El koymalar, tutuklamalar, sürgünler toplumsal tepkileri harekete geçirdi. Çeçen-İnguş Cumhuriyeti tam bir isyan alanı haline geldi. İsyancılar resmi kurumları işgal etti, hükümet görevlilerini tutukladı. 1930'da Sovyet Hükümeti bölgede bulunan bütün güçlerini seferber ederek Çeçenistan'ın dağlık kesimleri dışındaki bölgelerin tamamını işgal etti. Tepkilerin artması ve yayılması üzerine merkezi hükümet kolhoz uygulamasından vazgeçerek, isyancılar için af çıkarmak zorunda kaldı. Ancak, isyan liderlerinden İstamulov'un af belgesi verileceği vaadiyle çağrılıp öldürülmesi üzerine olaylar yeniden başladı. 35.000 kişi tutuklandı. Bu kişilerin çoğu ya idam edildi ya da hapishanelerde hayatını kaybetti (Şahin, 2000).

Bolşevikler, Rusya'dan başlayarak tüm insanlık için daha müreffeh bir toplum yaratarak dünyayı değiştirme iddiasıyla iktidara geldiler. Fakat bunu başaramadıkları gibi milyonlarca insanı baskı altına alarak, ceberut bir yönetim kurdular. Hosking'e göre, 1933'te Almanya'da Bolşevizm'i kökünden kazıyacağını ve Sovyet topraklarını işgal edip Alman'ları yerleştireceğini söyleyen Nazilerin iktidara gelmesi, Sovyet yönetiminin halka karşı şüphelerini iyice derinleştirdi, topluma karşı baskı ve şiddetin daha da artırmasına neden oldu. Halka karş1 duyulan güvensizlik, II. Dünya Savaşında uç noktasına vararak, SSCB içerisindeki milletlerin topluca sürgün edilmesine kadar vardı, "ihanet” ile suçlanan milletler yurtlarından sürgün edildiler. Önce 1941'de Rusya'da yaşayan Almanlar, ardından savaşın sonlarına doğru Kırım Tatarları ve Kuzey Kafkasya halkları, kamyon ve trenlere doldurularak son derece zor ve ilkel şartlar altında Sovyetler Birliğinin en uzak ve yaşam şartlarının en zor olduğu doğu bölgelerine sürüldüler (Hasanoğlu, 2016:4). Bu sürgün furyasında Çeçenler de nasibini aldı. Komşuları İnguşlarla birlikte 23- 24 Şubat 1944 tarihlerinde Nazilerle işbirliği yapmakla suçlanarak Kazakistan ve Sibirya'ya sürgün edildiler. Bu sürgün sırasında ve sonrasında on binlerce Çeçen hayatını kaybetti. Hayatta kalanların vatanlarına dönmelerine ancak Stalin'in ölümünden sonra, 1957 yılında Khrushchev döneminde yapılan politika değişikliği ile izin verildi (www.robertcutler.org/tr). Sovyet döneminde sürgünler öyle bir hâl almıştır ki, 1980'li yıllara gelindiğinde vatanlarından koparılarak farklı bölgelerde yaşamaya zorlanan halkların sayısı 60 milyonu aşmıştır (www.ayk.gov.tr). 
Çeçen -İnguş halkı Kuzey Kafkasya'dan çıkarıldıktan sonra 25 Haziran 1946'da Çeçen-İnguş Cumhuriyeti lağvedildi. Çeçenlerin ana vatana dönüşlerinin akabinde 9 Ocak 1957'de tekrar kuruldu. Sovyetler Birliği dağılıncaya kadar Cumhuriyet varlığını olaysız bir şekilde devam ettirmiştir (Şahin, 2000).

\subsection{Sovyet Sonrası Dönem}

80'li y1llarda askeri, siyasi, ekonomik, sosyal ve etnik açmazlar içinde bulunan SSCB, Gorbaçov'un Glastnost ve Perestroika politikaları sonucu 21 Aralık 1991'de Alma-Ata Antlaşması ile resmen dağıldı. 31 Mart 1992'de otonom cumhuriyetlerle Rusya Federasyonu arasındaki ilişkileri düzenleyen Rusya Federasyonu İçindeki Egemen Cumhuriyetlerin İktidar Organlart ile Rusya Federasyonu'nun Federal organlar Arasinda Yasama ve Yetkinin Paylaşılması Anlaşması imzalandı. Federasyon Anlaşması olarak bilinen bu anlaşmaya Tataristan ile Çeçen-İnguş Cumhuriyeti imza atmamıştır (Taşdemir ve Özer, 2017:146).

Sovyet sonrası dönemde, 1990'da toplanan Çeçen Ulusal Kongresi Cehar Dudayev'i başkan seçmiş, 1991 y1lında Dudayev'in öncülügünde gerçekleştirilen bir darbeyle Çeçenistan'da komünist yönetim devrilmiştir. 27 Ekim 1991'de yapılan seçimlerde Dudayev, Çeçenistan'ın ilk devlet başkanı seçilmiş, 1 Kasım 1991'de Meclis bağımsızlık kararı almış, 1 Şubat 1992'de de bu kararı ilan etmiştir (Akıl ve Küçükali, 2010:12). Ancak Moskova, seçim sonuçlarını ve bağımsızlık kararını tanımamıştır.

1991 Ağustos'unda Moskova'daki başarısız darbe girişiminden sonra, Rus Yönetimi Çeçen - İnguş Cumhuriyeti üzerindeki otoritesini sürdürmeye, siyasi çekişmelerden kaynaklanan zaaflarını bölgeye yansıtmamaya çalıştı. Bu amaçla Yeltsin, 19 Ekim 1991 tarihinde Çeçenistan'dan Rusya Federasyonu'nun Sovyet Meclisi tarafindan alınan kararları ve şartları kabul ederek imzalamasını istedi. Teklif, Dudayev tarafından reddedilerek, Çeçen millî muhafızlarının güç ve kapasiteleri artırılarak cevaplandırıldı. Bu süre zarfında Rusya Federasyonu, Çeçen Cumhuriyeti'ni Rusya'nın bir parçası olarak Federasyonu'nun yasalarına uymasını isterken, Çeçenistan, bağımsız bir devlet gibi hareket etmeye devam etmiştir (www. robertcutler.org/tr). Şubat 1992'de İnguşetya, Çeçenistan-İçkerya Cumhuriyeti'nden ayrılarak Rusya'ya katılmıştır.

Neticede, Rusya, Çeçenistan'ı kontrol etmekte başarısız olmuş, 1994 yılının ortasına kadar iki ayrı devlet olarak varlıklarını birlikte sürdürmüşlerdir. 1994 Şubat ayında, Rusya Federasyonu ile Mart 1992 tarihli Federasyon Anlaşması'nı imzalamayan diğer cumhuriyet olan Tataristan, Rusya Federasyonu'nun egemenliğini tanımaya karşılık, Tataristan'a geniş bir özgürlük veren bir anlaşma imzalamışlardır. Ancak Dudayev, Çeçenistan bağımsız bir devlet olarak tanınmadan ve uluslararası hukuka tâbi olmadan Rusya Federasyonu ile pazarlıklara başlamayı reddetmiş̧ir (www. robertcutler.org/tr).

1994 yılının ortalarına kadar Rus yönetimi, Çeçenistan'da meydana gelen gelişmeleri izlemekle yetinerek, müdahale etmedi. Bunun nedeni, Moskova'da Yeltsin, Gorbaçov ve komünistler arasında yaşanan iktidar mücadelesiydi. Çeçen Savaşı bu çekişme yüzünden üç yıl ertelenmek zorunda kaldı. Bu süre zarfında Rus yönetimi boş durmayarak hem Çeçenistan'a ekonomik ambargo uyguladı hem de, Çeçen muhalefetini "Geçici Konsey" adı altında, örgütleyerek Dudayev yönetiminin karşısına çıkardı. Moskova destekli muhalefet 26 Kasım 1994 tarihinde Çeçen milli güçlerine karşı saldırıya geçti. Saldırı Rusya tarafından Çeçenistan'daki demokratik güçlerce, demokrasi ve insan hakları adına gerçekleştirildiği duyuruldu. Ancak Moskova'nın açı desteğine rağmen muhalifler Dudayev kuvvetleri tarafından yenilgiye uğratıldı. Sorunu taşeron güçlerle çözemeyeceğini anlayan Yeltsin yönetimi, Çeçenistan'a doğrudan müdahale kararı aldı. 11 Aralık 1994'te Rusya Federasyonuna bağlı birlikler Çeçenistan'a girdi. Grozni ve nüfusun yoğun olduğu merkezler yerle bir edildi. Taraflar arasındaki güç farkına rağmen Çeçen güçler, 1995'ten 1996 yılına kadar şehir merkezleri dışında kalan büyük bir alanı, direnerek ellerinde tutmayı başardılar. Dönemin Rus Savunma Bakanı Pavel Grachev Çeçenistan'ın 2 saatte düşeceğini iddia etmesine rağmen savaş tam 21 ay sürdü. Ruslar on binden fazla asker, Çeçenler ise bir milyon civarında olan nüfuslarının yüzde onunu kaybettiler. Öyle ki, Çeçenler liderleri Dudayev'i bir Rus füzesiyle kaybettikleri halde 1996 Ağustos'unda başkent Grozni’yi tekrar ele geçirip, önemli bir zafere imza attılar (Yapıc1, 2013). 31 Ağustos 1996 günü imzalanan Hasavyurt Antlaşması ile Rusya yenilgiyi kabul ederek Çeçen topraklarından çekilmiş (Akıl ve Küçükali, 2010:13). Çeçenlere aşamalı olarak bağımsızlık vermeyi kabul etmiştir.

Sovyet Rusya dönemi sonrası gerçekleşen birinci Rus-Çeçen Savaşı self-determinasyon elde etme amaciyla gerçekleştirilen ilk dâhili başkaldırı hareketidir (www.disposition/com.tr). Çeçenistan'ın, Sovyetler Birliği'ni oluşturan Rusya, Ukrayna veya Estonya gibi on beş cumhuriyetten biri olmaması, hukuki varlığını devam ettiren Rusya Federasyonuna bağlı olması Çeçenistan'ın statüsü sorununu gündeme getirmiştir (Yapıcı, 2013). 
Sovyetler Birliğini oluşturan cumhuriyetler, Sovyetler Birliği dağılarak varlığı sonlandığı için özgürlüğüne kavuşurken, Çeçenistan Rusya Federasyonunun bir parçası kabul edilerek bu haktan mahrum edilmiştir.

1996 y1lında imzalanan Hasavyurt (Hasyurt) anlaşması ile savaş sona erse de etkileri büyük olmuştur. Rusya Federasyonu ile Çeçen Cumhuriyeti Arasında Karşılıklı İlişkilerin Dayanaklarını Belirlemek Iç̧in Prensipler ismini taşıyan bu anlaşmaya göre, Çeçenistan'ın Rusya içinde özel bir statüsünün olması kabul ediliyor. 31 Aralık 2001'den önce evrensel hukuk norm ve prensiplerine uygun olarak tarafların anlaşmaya varmaları öngörülüyordu. Beş yıl içinde Çeçenistan'ın bağımsızlığı için referandum yapılacak, Rus güçleri Çeçenistan'dan çekilecekti. Böylece Çeçenlerin self-determinasyon hakkı da güvenceye alınıyordu. 1997 Ocak ayında, şehit olan Dudayev'in yerine Aslan Maşhadov Cumhuriyetin yeni başkanı seçildikten sonra, bu anlaşma 12 Mayıs 1997'de aynen tekrarlanarak taraflarca kabul edildi (Şahin, 2000).

$\mathrm{Bu}$ anlaşma, hukuken olmasa da de facto olarak Çeçenistan'ın bağımsız bir devlet olarak varlığını ve eylemlerini kabul etmiştir. Uluslararası hukukçu Francis A.Boyle'ye göre; Rusya'nın Çeçenistan ile yaptığı bu anlaşma üç nedenden dolayı de facto Çeçen Cumhuriyeti'nin bağımsızlığının Rusya tarafından tanınması anlamına gelmektedir: Birincisi, "Rusya Federasyonu ile Çeçen Cumhuriyeti Arasındaki Barış ve İlişki Prensipleri Anlaşmasıdır". Zira uluslararası hukukta anlaşma sadece bağımsız devletler arasında yapılabilmektedir. Anlaşma ifadesi ile Çeçenistan'ın devlet olarak varlığı kabul edilmiştir. İkincisi, federal bir devlet ile onun bir parçası arasındaki ilişkilerin anayasa ile belirleniyor olmasıdır. Taraflar arasında akdedilen anlaşmanın hiçbir yerinde Rusya Federasyonu Anayasası'na atıf yapılmamıştır. Üçüncüsü ise anlaşmada Çeçenlerin kendilerine verdikleri isim olan "İçkerya Çeçen Cumhuriyeti" teriminin kullanılmasıdır. Bu ifade, Çeçenlerin kendilerine verdiği addır. Bu nedenle Rusya, de facto olarak Çeçenlerin bağımsızlığını tanımıştır. Boyle'ye göre, Çeçenistan'ın uluslararası tanınma için her zaman bu belgeyi kullanabilmesi mümkündür.

Daha önce belirtildiği gibi, yapılan anlaşmaya göre, Çeçenistan'ın nihai statüsüne 2001 yılında taraflar arasında yapılacak görüşmelerle karar verilecekti. Ancak, Çeçenistan Hükümetinden bağımsız hareket eden Şamil Basayev ile ABD istihbarat raporlarına göre Bin Ladin'in bölgedeki temsilcisi olan Arap kökenli Hattab'ın (Yapıc1, 2013) bir İslam devleti kurmak için Dağıstan'ın Botlikh bölgesini işgal edip savaşı yayması ve Rusya'ya karşı yapılan bombalı saldırılar Rusya'nın Çeçenistan'a yeniden müdahalesine sebep oldu. Çeçenistan'da üslenen grupların, komşu Dağıstan Cumhuriyeti'ne saldırmaları ve patlatılan bombalar, Rusya'ya aradığı müdahale firsatını vererek, sonun başlangıcını hazırladı (Yapıcı, 2013). Bu bombalamalarda üç yüz kişi hayatını kaybetti, yüzlercesi yaralandı. Bu savaş da, tıpkı birincisinde olduğu gibi binlerce sivilin ölümüne, 250 bin kişinin mülteci konumuna düşmesine neden olmuştur. Rusya bu müdahaleyi, 1996'da yürürlüğe giren, terörist ve ayrılıkçı grupların cezalandırılmasını öngören Çeçenistan ceza yasasının uygulanmaması ve Çeçenistan'ın Rusya Federasyonunun bir bileşeni olması ile gerekçelendirmiştir (Yapıc1, 2013). Kullberg'in ifadesiyle, Rusya bu son savaşla Çeçensiz bir Çeçenistan yaratarak yeniden kendine bağlamayı hedeflemiştir (Sapmaz, 2013:6).

Basayev'in Dağıstan'a girmesini, o tarihe kadar belirsiz olan Hazar petrollerinin statüsünün hukuki bir çözüme kavuşturulmamasıyla ilişkilendiren Anıl Çeçen, her ne kadar Hazar Denizine kıyısı olan Dağıstan, Rusya Federasyonu içinde kaldığından bazı petrol ülkeleri ile büyük petrol firmalarının Vehhabi hareketini örgütleyerek Dağıstan'a soktuklarını söylemekte ise de (www.dw.com/tr) çok sonra yapılan araştırmalarda işgalin Rusya Güvenlik Konseyi Sekreter Yardımcısı Boris Berezovskiy tarafından hazırlandığı ortaya çıkmış, Rusya İçişleri Bakan Yardımcısı Arkady Edelev de, Dağıstan'a yapılan militan saldırı ile ilgili olarak FSB üyeleri ile Boris Berezovskiy'nin karıştığına dair deliller ele geçirdiklerini açıklamıştır (https://lenta.ru/com.tr).

Sapmaz, Çeçen mücadelesinin tüm Kuzey Kafkasya'yı içine alan ümmetçi bir zemine kaymasında, sufi Nakşibendi geleneğinin yerini Ortadoğu'dan ithal edilen selefi Vahabi görüşlerin almasının büyük etkisi olduğu kanaatindedir. 2002'de Aslan Mashadov, gidişatı görerek radikalizmi dışlayan ve terörizmi kınayan bir kongre düzenlemek istemişse de Basayev ve ekibi tarafindan engellenmiş̧ir. Rusya'da patlatılan bombalar, 11 Eylül 2001 saldırılarının dünyadaki yankıları, mücadelenin Selefi-Vehabi ve yayılmacı bir eksene kayması uluslararası toplumun Çeçen mücadelesine bakışını da değiştirmiştir. 31 Ekim 2007'de Duko Umarov'un Kafkas Emirliğini ilan ederek bağımsız Çeçenistan fikrini bir tarafa atması (Taşdemir ve Özer, 2017:148) bölgedeki tüm laik yasaları kaldırdığını ve Afganistan, Irak, Somali ve Filistin'de savaştıklarını belirterek, Müslümanlarla savaşan herkesin kendilerinin düşmanı olduğunu ilan etmesi (Sapmaz, 2013:35) son sempati kırıntılarını da yok ederek Rusya'nın elini iyice güçlendirmiştir. Terör olayları münasebetiyle uluslararası meşruiyeti tartışılır hale gelen Çeçen mücadelesi zamanla hem etkisini, hem de uluslararası toplumun ilgisini kaybetti. Oysa Dudayev, yayılmacı bir politika yerine, "Son üç yüz yıldır Moskova bize birey olarak değil, ulus olarak yaşamayı ögretti" (Yapıcı, 2013) diyerek Çeçenistan ve Çeçen ulusu odaklı bir siyaset izlemiştir. Bu 
siyaset devam ettirilemediği için Çeçen mücadelesi Rusya'nın da etkisiyle, zaman içinde milli bir kurtuluş mücadelesinden bir terör sorununa dönüştürülmüştür.

Putin dönemi boyunca uluslararası toplumu etkilemeye yönelik kampanyalarla Çeçenistan'ın istikrara kavuştuğu yönünde bir algı yaratılmışsa da gerçekte çatışmalar daha az yoğunlukta devam etmiştir (Bingöl, 2013:37-1399).

Çeçen Millî Kongresi'nin dağıtılmasından sonra Çeçenistan hükümetini günümüzde İçkerya - Çeçen Cumhuriyeti, temsil etmektedir. Bu cumhuriyet, gerillâ savaşı yoluyla var olduğunu ve mücadelenin bitmediğini göstermeye çalışmaktadır. Bu amaçla küçük ölçekli eylemler yaparak uluslararası toplumun kaybolan ilgisini yeniden kazanmak istemektedir. Putin ise, yaptığı açıklama ile Çeçenistan'ın artık doğrudan Rusya'nın kontrolünde olduğunu ifade etmiş ve Stanislav Iliyasov'u yerel yönetimin başına getirmiştir. 08 Haziran 2001 tarihli kararname ile de doğrudan Rusya Federasyonu başkan ve hükümetine bağlı geçici bir Çeçen yönetiminin oluşturulması istemiştir (www.robertcutler.org/tr). Daha sonra, 07 Ekim 2003 'te Moskova'nın desteklediği aday Ahmet Kadirov Çeçenistan devlet başkanı seçilmiştir. 1995'de Çeçen müftüsü olduğu dönemde Rusya'ya karş1 cihat ilân eden Kadirov, 1998'de Çeçen liderlerini radikal İslâm'a kaymakla suçlayarak, Rusya'nın tarafına geçmiştir. Kadirov'un saf değiştirmesi üzerine onun liderliğinde Moskova'ya bağlı bir Çeçen gücü oluşturulmuştur. Böylece Çeçenler ikiye ayrılarak bir kısmı İslami bağımsızlık yanlılarını oluştururken, diğerleri de Rus üniforması giyerek Rusya adına onlarla mücadele yolunu tercih etmiştir (Sapmaz, 2013:199). 2004 Mayıs'ına kadar Çeçenistan'ı Rusya adına yöneten Ahmet Kadirov bu tarihte Grozni stadyumunda gerçekleştirilen bombalı bir saldırıda öldürülmüş, yerine oğlu Ramazan Kadirov geçmiştir. Çeçen yasalarına göre devlet başkanı olmak için 30 yaşını doldurması gereken Kadirov 27 yaşında olduğundan yerine 3 yıl boyunca İçişleri Bakanı Alu Alkanov bakmış, 2007'de yapılan göstermelik seçimlerle Devlet Başkanı yapılmıştır (www.insamer.com/tr/).

Her iki tarafta kesin netice almayı engelleyen düşük seviyeli saldırılardan hoşlanmamaktadır. Moskova, Çeçen komutanlarını devre dışı bırakacak, savaşı sonlandıracak ve cumhuriyet içinde yeni bir sosyal ve ekonomik yapılanmanın formülü peşindedir. Çeçen güçleri ise, hâlâ ayakta olduklarını ve savaşabilecek güçte olduklarını göstermek için askerî saldırılarına devam etme düşüncesindedirler. Görünen iki çözümden, -bağımsız Çeçenistan ya da Rusya Federasyonu içinde büyük ölçüde özerkliğe sahip Çeçenistan-, seçenekleri arasında sadece ikincisinin uygulanabilme şansı vardır (www. robertcutler.org/tr).

Çeçenistan, Rusya Federasyonu topraklarının sadece binde 5'ine sahiptir. Rusya tarafından bu kadar önem verilmesinin bir kaç sebebi vardır. En başta Çeçenistan'ın ayrılmasına izin vermenin domino etkisi yaparak federasyonun dağılmasına neden olacağı korkusudur. İkinci neden; Caharkale'deki (Grozni) zengin petrol yataklarıdır. 1932 yılına kadar Sovyetler Birliğinin petrol üretiminin üçte biri Grozni'den çıkarılmaktaydı. Sonraki yıllarda üretim düşmesine rağmen Çeçenistan petrol boru hatlarının geçtiği bir kavşak noktası olması bakımından önemini korumaktadır. Rus müdahalesinde bu hatlarla, Çeçen petrolünü güvenlik altına alma düşüncesinin etkili olduğu söylenebilir.

\section{SONUÇ}

Çeçen'lerin Ruslardan ayrı bir halk, dini, dili ve kültürleri ile farklı oldukları kesindir. Çeçenler, Kafkasya'nın yerli ve kadim halklarındandır. Ruslarla temas edinceye kadar bu bölgede bağımsız olarak varlıklarını sürdürmüşlerdir. Ruslarla temastan sonra da bazen çatışarak, bazen tabii olarak iç özerkliklerini korumuşlardır.

Diğer Kafkas halkları gibi Çeçenler de kabile ve aşiret düzeyinde parçalanmış bir halktır. Bu parçalanmışlık ve feodallerin çıkar çatışması ortak bir Çeçen milli kimliğinin oluşmasını engellemiştir. Sovyet öncesi dönemde bile kabile rekabeti ve çekişmeleri Rus Çarlığı ile Osmanlı İmparatorluğu arasında tercih farklılıklarına neden olmuştur. En kapsayıcı ortak değer olan İslam üzerinden ulusal bir kimlik inşa edilememiş, din milli kimliğin harcı yapılamamıştır. 1921'de Stalin'in tavsiyesi üzerine tek bir Sovyet Dağ Cumhuriyeti kurulduğunda bile, Cumhuriyetin içinde yer alan Çeçenistan, İnguşetya, Osetya, Kabarday, Balkar, Karaçay ve Dă̆ıstan halklarının her birinin ayrı bir padişahı bulunmaktaydı (Şahin, 2000). Şamil Basayev ve arkadaşlarının Çeçenistan'ın bağımsızlığını odağa almak yerine, güçlerini diğer bölgelere yaymaya çalışmaları da bu milli bilinç eksikliği ile ilgilidir.

Uluslararası hukuk, dış self-determinasyon hakkını sömürge halklarına, yabancı işgalinde olan halklara ve ırkçı, baskıcı rejimler altında yaşayan halklara tanımaktadır. Çeçenistan'ın Rus Federasyonu ile bitişik olması -tuzlu su doktrini- gereğince sömürge statüsünden yararlanmasına engel teşkil etmektedir. Ancak Çeçenistan bugün hem dolaylı bir işgal altında hem de ağır insan hakları ihlalleri ile karşı karşıyadır. Bir halkın iki Rus saldırısında yüzde 10'una tekabül eden bir insan varlığını kaybetmesi, sürgünler, idamlar ve yargısız infazlarla 
karşı karşıya kalması bunun en açık ispatıdır. Uluslararası hukuk, artık insan hakları ihlallerini devletlerin içişlerine ait bir sorun olarak görmemekte, milli sınırları aşan uluslararası bir sorun olarak ele almaktadır.

2003 yılından itibaren yapılan seçimlerin Çeçen halkının gerçek iradesini yansıtıp yansıtmadığı belli değildir. Avrupa Konseyi delegasyonu adına 2005 seçimlerini izleyen başkan yardımcısı Rudolf Bindig, "Korkunun hâkim olduğu, askerlerin yaşamın her alanında hissedildiği bir yerde, özgür ve adil seçimlerden söz edilemeyeceğini, Çeçenistan'daki seçimlerin özgür ve adil şartlarda yapılmadığını ifade etmiştir" (www.dw.com/tr).

Rusya'nın güç dengelerinde işgal ettiği konum bugün bu meselenin evrensel hukuk kurallarının hakemliği altında çözümünü zorlaştırmaktadır. Çeçen halkının uluslararası hukuka göre kendi kaderini belirleme ve ayrılma hakkı vardır. Bir halk, hatta devlet oldukları 1996'da imzalanan Hasyurt anlaşması ile kabul edilmiştir. Rusya ile Çeçenistan arasında tam altı antlaşma akdedilmiş olup bu antlaşmalar Çeçenistan'ın zımnen devlet olarak tanınması anlamına gelmektedir. İç hukuka göre de ayrılma hakkı vardır; 1977 tarihli S.S.C.B. Anayasası'nın 71 ve 73. maddeleri açıktır:

\section{M.71: S.S.C.B.'nin birleşik eşit Sovyet Sosyalist Cumhuriyetleri, olarak gönüllü bir birliktelik sağladıklart ve milletlerin kendi kaderlerini tayin etme haklarina dayanan sosyalist federalizm ilkeleri çerçevesinde çok milletle oluşmuş bir federal devlettir. S.S.C.B; Sovyet halklarının ve içindeki millet ve milliyetlerin komünizmi birlikte inşa etmek için devlet birliğinde bir araya geldikleri halleridir.}

\section{M.73: Birlikteki her Cumhuriyet'in S.S.C.B. den ayrlma haklarl saklıdır (Yaman, 2017:146).}

Çeçenistan, hem yabancı bir gücün işgali altında hem de zorba, baskıcı, halkın istek ve taleplerine kapalı bir yönetim tarafından idare edilmektedir. Toprakları, Tataristan veya Çuvaşistan Cumhuriyetleri gibi Rusya Federasyonu toprakları ile çevrili değildir. Gürcistan ile sınırı vardır. Dolayısıyla Rusya içi bir bölge olarak değerlendirilip SD hakkından mahrum olduğu düşünülemez. Sovyetler Birliği Kurulmadan bağımsız bir cumhuriyet olan Çeçenistan, Kızıl Ordu'nun işgali ve zorla Sovyetler Birliği şemsiyesi altına alınmıştır. Rusya Federasyonu kurulmadan önce de bağımsızlığını ilan etmiş ve on yıl de facto olarak bağımsızlığını korumuştur. Basayev ve arkadaşlarının Dağıstan'a yönelik girişimlerine rağmen, ikinci müdahaleye zemin hazırlayan Volgograd ve Dağıstan'daki patlayan bombalarla ilgilerinin olmadığı ortaya çıkmıştır. Bunu Putin'in güç ve popülaritesini artırmak için iç istihbaratın yaptığı bugün neredeyse kesinlik kazanmıştır (Levitsky ve Ziblatt 2018:12). Çeçenistan'a ikinci müdahalesini terörist faaliyetleri bahane ederek meşrulaştıran Rus yönetimi aslında terör yöntemlerini kendisi kullanmaktadır. Birçok Çeçen lider, sığındıkları ülkelerde terörist metotlarla öldürülmüştür.

Rusya, Kadirov üzerinden Çenistan'da kontrolü sağlayabilmek için her türlü çareye başvurmaktadır. Kadirov, 5 bin kişilik ordusu, kullandığı terörist yöntemler ve muhaliflere uyguladığı ağır işkencelerle tam bir korku imparatorluğu kurmuştur. Çeçen direnişinin ateşleyici gücünün din faktörü olduğu dikkate alınarak özgürlükçü, bağımsızlıkçı bir din anlayışı yerine, siyasete müdahil olmayan teslimiyetçi, ferdi ahlaka dönük bir din anlayışı hâkim kılınmaya çalışılmaktadır. Bunun için de sosyal yönü olmayan mistik bir tasavvuf anlayışı empoze edilmektedir. $\mathrm{Bu}$ amaçla dünyanın çeşitli yerlerinden din adamları davet edilmekte, konferanslar tertip edilmektedir. 2008 yılında 200 din adamının katıldığı, "Íslam Dünyasında Sufiliğin Yeri ve Rolü" isimli bir konferans düzenlenmiş, bu vesileyle hem Rusya'nın Sovyetlerden kalan din karşıtı imajının değiştirilmesi hedeflenmiş, hem de bireysel ahlaktan ibaret bir din anlayışı telkin edilmiştir. Konferans, görünüşte Libya merkezli "Dünya İslam Halkları Liderliği" isimli örgüt tarafından organize edilmesine rağmen Rus Hükümeti tarafindan finanse edilmiştir (www.ajanskafkas.com/tr). Hedef, uyandıran bir din anlayışı yerine uyutan bir din anlayışını hâkim kılmaktır. Din, ferdi ahlak ve ibadetlerle sınırlandırılınca ülkeyi kim veya kimlerin yönettiği de bir sorun olmaktan çıkmaktadır. Kadirov'un göreve gelmesinin ardından belli saatlerde içki satışı ve kadınların mini etekle sokağa çıkışının yasaklaması da aynı maksada matuftur (www.insamer.com/tr/). Dini; özgürlük ve bağımsızlık ateşini söndürmek için kullanmak. Ancak Rusya'nın Çeçenistan'a yönelik politikaları yeni bir din anlayışını hâkim kılmaktan ibaret değildir. 1.12.1994 tarih ve 1887 P numaralı Rus Başbakanı Çernomirdin imzalı gizli bir belgede, Çeçen direnişi kırıldıktan sonra Çeçen halkının yok edilmesi de emredilmektedir. (www.dw.com/tr).

Çeçenler'in Ruslar'dan ayrı bir halk olduklarına şüphe yoktur. Yaşadıkları topraklar kadimden beri kendilerine ait topraklardır. Rusların Kafkasya'yı işgaline kadar kendi kendilerini yönetmişler, Ruslar bölgeye gelince de uzun yıllar sürecek bir mücadeleye girişmişler, hiç bir zaman yenilgiyi kabul etmemişlerdir. Soykırım derecesine varan katliamlara ve sürgünlere rağmen her seferinde yeniden ayağa kalkmış, bıraktıkları noktadan özgürlük mücadelelerini sürdürmüşlerdir. 
İkinci, Çeçen-Rus savaşı on binlerce Çeçen'in ölümüne neden olmuştur. Hemen her aile birçok ferdini kaybetmiştir. Son iki asırda Çeçen tarihi adeta Rus-Çeçen mücadeleleriyle yazılmıştır. Çeçen halkının acıları hala tazeliğini korumakta, kendi kaderlerini belirleme arzusu bugün yok gibi görünse de gerçekte şartlarının oluşacağı günü beklemektedir.

Çeçenistan'ın durumu, iyileştirici hak teorilerinin zorba yönetim ve yabancı işgali kriterlerine uymaktadır. Hem yabancı işgali altında, hem de ırkçı, baskıcı, siyasete özgür katılım imkânının olmadığı zorba bir yönetim altındadır. Ancak Rusya'nın bugünkü gücü ve uluslararası alandaki konumu, nüfuzu bağımsız bir Çeçenistan'1 imkânsız kılmaktadır. Gerçek ile ütopya arasındaki doğru tercih; Çeçen halkının iç işlerinde kendi geleceğini tam bir özgürlük içinde belirlemesidir. Günümüzde self-determinasyon hakkına sahip olmak özgürlük için yetmemektedir. Bu hakka sahip olmanın yanında Çeçenistan için diğer bazı şartların da bulunması gerekmektedir. Bunlar; uluslararası konjonktür, zayıf bir Rusya ve kabilecilikten kurtulup ortak bir milli kimlik oluşturmuş Kafkas halkı.

\section{KAYNAKÇA}

AHMADOV, Yavus (2000), Çeçen-İnguşya Halkıyla Rusya Arasındaki İlişkiler, Sorun Yayınları, İstanbul.

AKIL, Abdülkadir ve KÜÇÜKALİ, Canan (2010), "Uluslararası Hukuk Bakımından Kendi Kaderini Tayin Etme Hakkı ve Çeçenistan Sorunu", Yeni Fikir Dergisi, S.2(4), ss.6-19.

ALTUN, Fatih Mustafa (2011), "Çeçen Sorunu ve Rusya 'nın Terörle Mücadele Politikaları", E-Makale, ss.116,https://www.academia.edu/18266141/\%C3\%87e\%C3\%A7en_Sorunu_ve_Rusyan\%C4\%B1n_Ter\%C3 \%B6rle_M\%C3\%BCcadele_Politikalar\%C4\%B1 (Erişim Tarihi: 25.03.2017).

ANDREİ, Smirnov (2008), "Çeçenya'da Selefi Sufi Mücadelesi", North Caucasus Weekly, S.9(27), http://ajanskafkas.com/konuk-yazarlar/cecenyada-selefi-sufi-mucadelesi/ (Erişim Tarihi: 27.04.2018).

ASLAN, Cahit (2006), Bir Soykırımın Adı: 1864 Büyük Çerkez Sürgünü, ASAM Yayınları, Ankara.

BERAN, Harry (1987), The Consent of Political Obligation, Croom Helm Puplishers, London.

BİNGÖL, Oktay (2013), "Rusya'nın Kuzey Kafkasya'yı Kontrol Stratejilerinde Gelinen Aşama: Başarısızlık ve Terör", Karadeniz Araştırmaları Dergisi, S.37, ss.137-158.

BUCHANAN, Allen (1991), Secession: The Morality of Political Divorce from Fort Sumter to Lithuania And Quebec, Boulder CO, Westview.

CASSESE, Antonio (1998), Self-Determination of Peoples: a Legal Reapprasial, Cambridge Unıversty Press, Cambridge.

CAŞIN, Mesut Hakkı (2013), Modern Uluslararası Hukukun Temel Esasları, Legal Yayıncılık, İstanbul.

CUTLER, Robert M. (2004), "Kafkasya'daki Kriz Kaynakları ve Bölgeleri", Türkiye, NATO ve AB Perspektifinden Kriz Bölgelerinin İncelenmesi ve Türkiye'nin Güvenliğine Etkileri Sempozyumu Bildiriler Kitabı, (27-28 Mayıs 2004 - İstanbul), SAREM Yayınları, Ankara, ss.115-116.

ÇEÇEN, Anıl (2019), Çeçenistan Dosyası, Astana Yayınları, Ankara.

EHTIBARLI, Yaşar (2016), Uluslararası Hukukta Self-Determinasyon Hakkı ve Hakkın Ekonomik Boyutu, Seçkin Yayıncılık, Ankara.

EMINOĞLU, Ayça (2015), "Uluslararası Politikada Devletlerin Tanınması, Ayrılma İle Ortaya Çıkan Devletlerde Tanınma Sorunu", Karadeniz Teknik Üniversitesi SBE Sosyal Bilimler Dergisi, S.5(9), ss.123-141.

HASANOĞLU, İbrahim (2016), "Ahıska Türkleri: Bitmeyen Bir Göç Hikayesi", Türk Dünyası İncelemeleri Dergisi, S.16(1), ss.1-20.

KALAYCI, Hüseyin (2010), Ulus Devletlerin Başağrısı Ayrılıkçılık, Liberte Yayınları, Ankara.

KILIÇ, Doğan (2008), "Self Determinasyon İlkesinin Azınlıklar Açısından Değerlendirilmesi", Gazi Üniversitesi Hukuk Fakültesi Dergisi, S.12(1-2), ss.949-982. 
LENTA.RU (2007), "Березовский подтвердил факт финансирования Басаева", E-Haber, https://lenta.ru/news/2007/06/02/confirm/ (Erişim Tarihi: 10.06.2019).

TIMUR, Mehmet (2018), "Çeçenistan'ın Unutulan Hikayesi ve Kadirov Ailesi", İNSAMER Kurumsal Web Sayfası, https://insamer.com/tr/cecenistanin-unutulan-hikyesi-ve-kadirov-ailesi_1204.html (Erişim Tarihi: 26.04.2018).

NIMNI, Ephraım (2016), "Uluslar, Bölgesel Azınlıklar, Demokratik Teori ve Ulusal Kendi Kaderini Tayin Hakkı", 21.Yüzyılda Milliyetçilik (Ed. Elçin Aktoprak, A. Celil Kaya; Çev. Osman İşçi), İletişim Yayınları, İstanbul.

LEVITSKY, Steven ve ZIBLATT, Daniel (2018), Demokrasiler Nasıl Ölür (Çev. Derya Dinç), Salon Yayınları, Konya.

SAPMAZ, Ahmet (2013), "Rusya Federasyonunun Terörle Mücadele Stratejisinin Kuzey Kafkasya'nın İstikrarı Üzerine Etkileri", Savunma Bilimleri Dergisi, S.12(2), ss.1-35.

SEFA Sole (2017), "Rusya Çeçenistan Savaşı: Geçmişten Günümüze", E-Makale, https://www.stratejikortak.com/2017/04/rusya-cecenistan-savasi.html (Erişim Tarihi: 25.03.2017).

ŞAHIN, Mustafa (2000), Avrupa Birliğinin Self-Determinasyon Politikası, Nobel Yayınları, Ankara.

TASAM (2011), "Kafkasyada Bir Ülke: Çeçenistan", TASAM Kurumsal Web Sayfası, https://tasam.org/trTR/Icerik/2213/kafkasyada_bir_ulke_cecenistan (Erişim Tarihi: 25.03.2018).

TAŞDEMIR, Fatma ve ÖZER, Adem (2017), Uluslararası Hukuk Perspektifinden Self-Determinasyon ve Ayrılma, Hukuk Yayınları, Ankara.

ÜLGER, İrfan Kaya (2011), "Rusya Azınlıkları", 38. ICANAS Bildiri Özetleri Kitabı, (10-15 Eylül 2007 Ankara), Atatürk Kültür, Dil ve Tarih Yüksek Kurumu Yayınları, Ankara, ss.1399-1415, http://www.ayk.gov.tr/wp-con/2015/ (Erişim Tarihi: 25.03.2018).

YAMAN, Aslan (2017), Sovyetler Birliğinden Rusya Federasyonuna Sovyet Sosyalizminin Anayasaları, Doğu Kütüphanesi Yayınları, İstanbul.

YAPICI, Utku (2013), Tarihsel Süreç İçinde Rus-Çeçen Sorunu, Kafkasevi Sosyal ve Stratejik Araştırmalar Merkezi Yayını, Çankırı.

YEŞiL, Caner (2005), "Çeçenistan Sorunu ve Günümüzde Çeçenistan", E-Makale, https://www.academia.edu/7181956/\%C3\%87E\%C3\%87EN_SORUNU_VE_Rapor_ (Erişim Tarihi: 25.03.2018).

YEŞiL, Caner (2014), "Sovyet Sonrası Dönemde Çeçen Direnişi İslami Temelli Müridizm Mi? Yoksa Radikal İslam Terörümü?", E-Makale, https://s3.amazonaws.com/academia.edu.documents/33678606 (Erişim Tarihi: 25.03.2018). 